\title{
Effects of D-penicillamine on growth and cell cycle kinetics of cultured rabbit articular chondrocytes
}

\author{
PATRICK JAFFRAY, ${ }^{1}$ XAVIER RONOT,${ }^{1}$ MONIQUE ADOLPHE, ${ }^{1}$ \\ JANINE FONTAGNE, ${ }^{2}$ AND PAUL LECHAT ${ }^{2}{ }^{2}$ \\ From the ${ }^{1}$ Laboratoire de Pharmacologie Cellulaire de l'Ecole Pratique des Hautes Etudes, Institut Biomédical \\ des Cordeliers, and the ${ }^{2}$ Laboratoire de Pharmacologie de l'Association Claude Bernard, Institut Biomédical \\ des Cordeliers, 15 rue de l'Ecole de Médicine, 75006 Paris, France
}

SUMMARY The long-acting antirheumatic drug D-penicillamine was found to inhibit the growth of asynchronous cultures of rabbit articular chondrocytes. This inhibitory effect was dose-related between $5 \cdot 10^{-4} \mathrm{M}$ and $5 \cdot 10^{-3} \mathrm{M}$ and was time-dependent for a given dose. Flow cytometric analysis showed that drug exposure led to a slowdown in cell cycle progression. This was manifested as a decrease in the number of cells in $S$ phase, due especially to an accumulation of cells in $G_{0} G_{1}$ and also to a slight cessation of cell transit through $\mathrm{G}_{2} \mathrm{M}$. Recovery experiments showed that the effect is transitory and reversible. It is suggested that the articular chondrocyte is a target cell for $D$-penicillamine and that these cells have a D-penicillamine sensitive restriction point in the $G_{0} G_{1}$ phase of the cell cycle and to a less extent in the $G_{2} M$ phase.

D-penicillamine, a drug used for the treatment of Wilson's disease, ${ }^{1}$ heavy-metal poisoning, ${ }^{2}$ and cystinuria ${ }^{3}$ has been shown to have a beneficial effect on the course of rheumatoid arthritis. ${ }^{4}$ The thiol group is responsible for the interaction with disulphide bridges and with thiol groups in biological systems, while both the amino and thiol groups are involved in the interaction with aldehydes and chelation of heavy metals. ${ }^{5}$ These properties account for some of the effects observed during D-penicillamine treatment of rheumatoid arthritis-for example, a diminution of rheumatoid factor and of circulating immune complexes $^{6-8}$-but the mechanism underlying its therapeutic efficacy in this disease still remains obscure. D-penicillamine has also been shown to affect macrophage functions ${ }^{9}$ and lymphocyte proliferation. ${ }^{10}$ It reduces the proliferation of fibroblasts and rheumatoid synovial cells in culture. ${ }^{11}$

Its action on articular chondrocytes, a cell type particularly implicated in rheumatoid disease, had not been investigated. The present studies were undertaken: $(a)$ to establish if the articular chondrocyte is a target cell for D-penicillamine via its proliferation suppressing activity; and $(b)$ to investigate the effects of D-penicillamine on the cell growth parameters by means of flow cytometric analysis.

Accepted for publication 5 May 1983.

Correspondence to Dr M. Adolphe.

\section{Material and methods}

Origin and culture of chondrocytes. Articular cartilage was removed from the shoulder and knee joints of 1- to 2-month old rabbits, Fauve de Bourgogne. Chondrocytes were enzymatically released from cartilage slices by the technique of Green, ${ }^{12}$ which gives a pure population of chondrocytes. Isolated cells were then cultured in HAM F 12 medium with $10 \%$ fetal calf serum and penicillin-streptomycin added. The medium was changed every second day after cell attachment had occurred, and the cuiture was maintained at $37^{\circ} \mathrm{C}$ in an atmosphere of $5 \% \mathrm{CO}_{2}$. After the cells reached the plateau growth phase they were detached with trypsin, and the subculture was used for the present study.

Drug. D-penicillamine hydrochloride was purchased for Sigma. Drug solutions were prepared on the day of the experiment by dissolving D-penicillamine in HAM F 12 medium. Serial appropriate dilutions were made at room temperature.

Cell growth. $35 \mathrm{~mm}$ plastic Petri dishes were seeded with $7 \times 10^{4}$ cells. After one day of culture the dishes received fresh medium containing D-penicillamine hydrochloride at the appropriate concentration. After 24, 48, and 72 hours' incubation cells were collected by trypsinisation and the growth of control and treated cells was measured by cell 
counts. Cell growth was monitored by counting viable cells-defined by their ability to exclude trypan blue. Cultures were tested in triplicate and each count was performed twice. For recovery experiments the drug media were removed on the selected day, the cells were washed, and fresh medium without drug was added.

Clonability studies. Chondrocyte cultures were trypsinised, and a single cell suspension was prepared by gentle pipetting. 200 cells were plated into $35 \mathrm{~mm}$ Petri dishes containing 2 ml of HAM F 12 with $10 \%$ fetal calf serum. After 24 hours of incubation cultures were treated with D-penicillamine at the appropriate concentrations, and the clonal plates were incubated undisturbed for 10 days at $37^{\circ} \mathrm{C}$ in a $5 \% \mathrm{CO}_{2}, 95 \%$ air. The cells were then fixed with methanol and stained with toluidine blue. Plating efficiency was measured in triplicate.

Flow microfluorometry. Cells were seeded at a density of $5 \times 10^{5}$ per $25 \mathrm{~cm}^{2}$ plastic flask. After one day of culture the flasks received fresh medium containing D-penicillamine at the appropriate concentration. Monolayer cultures were harvested by trypsinisation after various time treatments $(12,24,48$, 72 hours) with D-penicillamine. Single cell suspensions were fixed in $70 \%$ ethanol, treated with ribonuclease, and stained with propidium iodide as described by Crissman and Steinkamp. ${ }^{13}$ The relative DNA content was determined by the Cytofluorograf FC 200 (Ortho-Instruments). The cell cycle distributions were calculated according to a modification of the computer program established by Fried and Mandel. ${ }^{14}$ The frequency distribution histograms of DNA content obtained in this way were always compared with the appropriate controls. All cytokinetic experiments were run in duplicate and repeated at least 3 times and gave similar results.

\section{Results}

\section{CELL PROLIFERATION}

The addition of D-penicillamine to cultures resulted in an inhibition of cell proliferation (Fig. 1). D-penicillamine treatment for 24 hours did not markedly affect the rate of cell growth. However, the highest doses $5 \times 10^{-3}$ and $3.5 \times 10^{-3} \mathrm{M}$ produced a slight but significant $(p<0.05)$ inhibition effect. By contrast, prolonging the treatment of 48 or 72 hours led to an important inhibition of cell growth which was dose-dependent between $5 \times 10^{-3} \mathrm{M}$ and $5 \times 10^{-4} \mathrm{M}$. A dose of $5 \times 10^{-3} \mathrm{M}$ was required to obtain a maximal effect of cell growth inhibition in less than 48 hours. In this situation there was an almost total arrest of the proliferation between the second and third day, with a reduction of the cell number to about $70 \%$ of the control values. For the

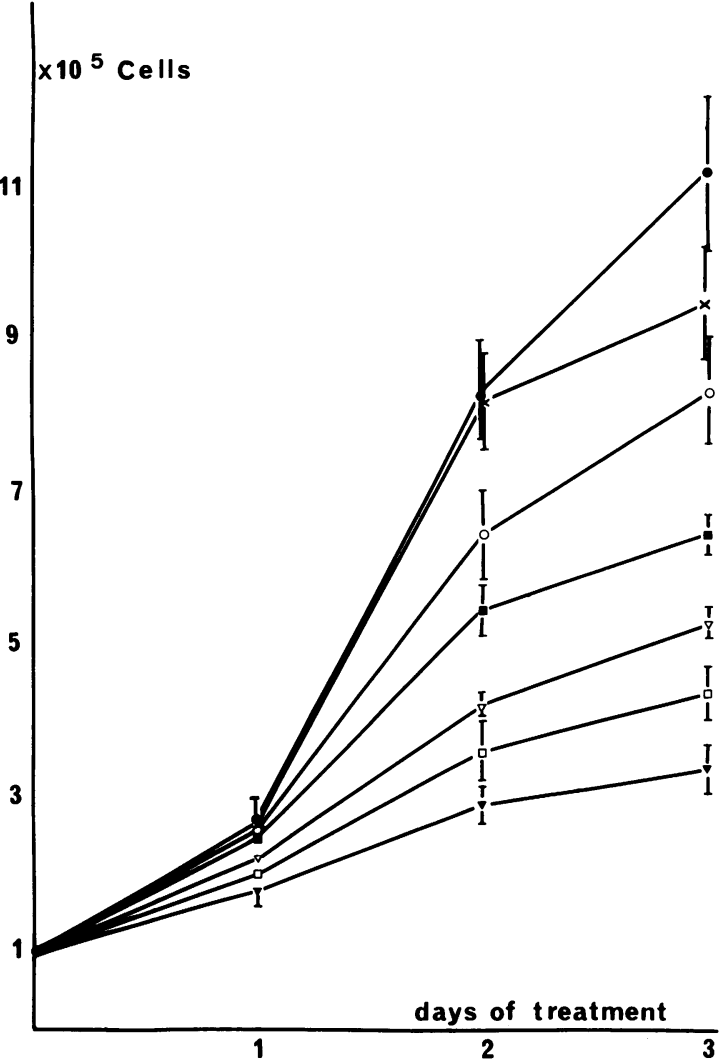

Fig. 1 Effects of various concentrations of D-pencillamine on the growth of asynchronous rabbit articular chondrocytes. Cells were seeded at a density of $7 \cdot 10^{4}$ cells/Petri dish and incubated at $37^{\circ} \mathrm{C}$ in an atmosphere of $5 \% \mathrm{CO}_{2}$ in air. After 24 hours of 'adaptation' the cells were exposed to selected

D-penicillamine concentrations. After 24, 48, 72 hours' incubation the cells were collected by trypsinisation and counted. $\bigcirc$ control, $\times-\times 5 \cdot 10^{-4} \mathrm{M} \bigcirc-\bigcirc 10^{-3} \mathrm{M}$ $\square-\square 1 \cdot 5.10^{-3} M \nabla-\nabla 2 \cdot 5 \cdot 10^{-3} M \square-\square 3 \cdot 5.10^{-3} M$ $\nabla-\nabla 5 \cdot 10^{-3} M$. Each point is the mean of triplicate cultures \pm 2 SEM.

intermediate doses, $3.5 \times 10^{-3} \mathrm{M}$ to $10^{-3} \mathrm{M}$, the effect was always important and was time-dependent for a given concentration. On day 3 this led to a proliferation reduction in the range between $60 \%$ for $3.5 \times 10^{-3} \mathrm{M}$ and $30 \%$ for $10^{-3} \mathrm{M}$. With $5 \times 10^{-4} \mathrm{M}$ the proliferation value was very close to control values (reduction of $15 \%$ ). None of the concentrations used caused cell detachments from Petri dishes, and cell viability on day 3 was about $90 \%$ in both treated and control cells. To ascertain whether this proliferation inhibition was reversible the drug medium was removed on day 3 and the cells were incubated in 
drug-free medium for another 3 days. The numerical values on day 6 (Table 1 ) show that the cells kept their proliferative capacity.

Clonability studies. Only the doses which were effective on cell growth were tested. Table 2 shows

Table 1 Recovery experiment

\begin{tabular}{lcc}
\hline D-penicillamine & $\begin{array}{l}72 \mathrm{~h} \text { drug treatment } \\
\text { (number of } \\
\text { cells } \times 10^{3}\end{array}$ & $\begin{array}{l}72 \mathrm{~h} \text { drug treatment } \\
+72 \mathrm{~h} \text { drug-free } \\
\text { medium (number of } \\
\text { cells } \times 10^{3} \text { ) }\end{array}$ \\
\hline 0 & $1130 \pm 102$ & $1150 \pm 46$ \\
$5 \cdot 10^{-3} \mathrm{M}$ & $340 \pm 32$ & $950 \pm 80$ \\
$3 \cdot 510^{-3} \mathrm{M}$ & $440 \pm 36$ & $820 \pm 34$ \\
$2 \cdot 510^{-3} \mathrm{M}$ & $510 \pm 20$ & $840 \pm 62$ \\
$1 \cdot 510^{-3} \mathrm{M}$ & $650 \pm 26$ & $980 \pm 62$ \\
$10^{-3} \mathrm{M}$ & $820 \pm 78$ & $1000 \pm 84$ \\
$5 \cdot 10^{-4} \mathrm{M}$ & $950 \pm 80$ & $1100 \pm 60$ \\
\hline
\end{tabular}

Cells were cultured for 72 hours in the presence of D-penicillamine at various concentrations. At the 72nd hour the D-penicillamine incubation medium was removed, cells were washed, and fresh medium was added. At the end of experiments the cells were collected by trypsinisation and counted. Each value is the mean of triplicate cultures \pm 2 SEM.

Table 2 Effect of D-penicillamine treatment on plating efficiency of articular chondrocytes

\begin{tabular}{lll}
\hline D-penicillamine & $\begin{array}{l}\text { Number of clones } \\
(50 \text { cells })\end{array}$ & $\begin{array}{l}\text { Plating efficiency } \\
(\%)\end{array}$ \\
\hline 0 & $72 \pm 5^{*}$ & 36 \\
$5 \cdot 10^{-3} \mathrm{M}$ & $26 \pm 5$ & 13 \\
$3 \cdot 510^{-3} \mathrm{M}$ & $39 \pm 1$ & 19 \\
$2 \cdot 510^{-3} \mathrm{M}$ & $42 \pm 2$ & 21 \\
$10^{-3} \mathrm{M}$ & $57 \pm 6$ & 28 \\
\hline
\end{tabular}

*Mean \pm SD.

200 cells were plated into $35 \mathrm{~mm}$ Petri dishes containing $2 \mathrm{ml}$ of HAM F 12 medium with $10 \%$ fetal calf serum. The clonal plates were incubated for 10 days at $37^{\circ} \mathrm{C}$ in a $5 \% \mathrm{CO}_{2}, 95 \%$ air atmosphere. The cells were fixed with methanol and stained with toluidine blue. Clones with more than 50 cells were scored and plating efficiency determined. Each value is the mean of triplicate cultures. their effect on clonal growth. The plating efficiency of controls was $36 \%$. D-penicillamine induced a marked decrease in cell proliferation with a plating efficiency from $13 \%$ for $5 \times 10^{-3} \mathrm{M}$ to $28 \%$ for $10^{-3} \mathrm{M}$.

Flow cytometric analysis. In order to study the repartition of control and treated cells in the different phases of the cell cycle during these periods, flow cytometric analysis was carried out after $12,24,48$, and 72 hours' treatment. Two concentrations were tested: $5 \times 10^{-3}$ and $10^{-3} \mathrm{M}-$ i.e., the highest and the lowest concentrations which markedly affect cell growth. These experiments showed significant differences in the repartition of cells in the cell cycle between control and treated cells. The treated cells showed a diminution of the relative number of cells in $S$ phase, an accumulation of cells in $G_{0} G_{1}$, and also a slowdown in the passage in the $\mathrm{G}_{2} \mathrm{M}$ phase. Indeed, a 12-hour treatment with $5 \times 10^{-3} \mathrm{M}$ reduced the relative number of cells in $S$ phase from $27 \%$ for the control to $13 \%$ (Table 3(a)) and enhanced the equivalent number of cells in $G_{0} G_{1}$ phase $(65 \%$ for $5 \times 10^{-3} \mathrm{M}$ compared with $54 \%$ for the control). The proportion of cells in the $\mathrm{G}_{2} \mathrm{M}$ phase did not change appreciably $(22 \%$ compared with $19 \%$ for the control). The $10^{-3} \mathrm{M}$ concentration had no effect on cell distribution during this incubation period. A 24-hour treatment with $5 \times 10^{-3} \mathrm{M}$ (Table 3(b)) further reduced the relative number of cells in $\mathrm{S}$ phase $(9 \%$ compared to $18 \%$ for the control-i.e., a diminution of $50 \%$ - and increased the cells in $\mathrm{G}_{0} \mathrm{G}_{1}$ phase $(71 \%$ compared with $61 \%$ for the control). We observed also an important proportion of treated cells in $\mathrm{G}_{2} \mathrm{M}$ phase-20\%, a value similar to that of the control cells but which is twice as high as that of the cells in $\mathrm{S}$ phase, suggesting a slowdown of cells in $G_{2} M$ phase or a partial cessation of cell transit through this phase.

Fig. 2 represents a typical distribution histogram obtained with $5 \times 10^{-3} \mathrm{M}$ treatment at the 24 th hour. However, no effect could be seen with the $10^{-3}$

Table 3 Percentage cells in $G_{0} G_{1} S$, and $G_{2} M$ after $D$-penicillamine treatment determined by using flow cytometric analysis

\begin{tabular}{|c|c|c|c|c|c|c|c|c|c|c|c|c|}
\hline \multirow[t]{2}{*}{ D-penicillamine } & \multicolumn{3}{|c|}{$12 h(a)$} & \multicolumn{3}{|c|}{$24 h(b)$} & \multicolumn{3}{|c|}{$48 h(c)$} & \multicolumn{3}{|c|}{$72 h(d)$} \\
\hline & $G_{0} G_{1}$ & $S$ & $G_{2} M$ & $G_{0} G_{1}$ & $S$ & $G_{2} M$ & $G_{0} G_{1}$ & $S$ & $G_{2} M$ & $G_{0} G_{1}$ & $S$ & $G_{2} M$ \\
\hline $\begin{array}{l}0 \\
10^{-3} \mathrm{M} \\
5 \cdot 10^{-3} \mathrm{M}\end{array}$ & $\begin{array}{l}54 \pm 4 \\
58 \pm 10 \\
65 \pm 3^{*}\end{array}$ & $\begin{array}{l}27 \pm 4 \\
24 \pm 5 \\
13 \pm 3^{*}\end{array}$ & $\begin{array}{l}19 \pm 3 \\
18 \pm 3 \\
22 \pm 1\end{array}$ & $\begin{array}{l}61 \pm 2 \\
61 \pm 3 \\
71 \pm 1^{*}\end{array}$ & $\begin{array}{c}18 \pm 4 \\
18 \pm 4 \\
9 \pm 1^{*}\end{array}$ & $\begin{array}{l}21 \pm 4 \\
21 \pm 4 \\
20 \pm 2\end{array}$ & $\begin{array}{l}72 \pm 2 \\
76 \pm 2^{*} \\
76 \pm 2^{*}\end{array}$ & $\begin{array}{r}11 \pm 1 \\
9 \pm 1 \\
9 \pm 1\end{array}$ & $\begin{array}{l}17 \pm 4 \\
15 \pm 3 \\
15 \pm 1\end{array}$ & $\begin{array}{l}89 \pm 1 \\
79 \pm 1^{*}\end{array}$ & $\begin{array}{l}2 \pm 1 \\
2 \pm 1\end{array}$ & $\begin{array}{c}9 \pm 2 \\
19 \pm 2 *\end{array}$ \\
\hline
\end{tabular}

Mean values \pm SD.

Growing cells of chondrocytes $\left(5 \cdot 10^{5}\right.$ cells per flask) were plated after 24 hour culture with D-penicillamine: $10^{-3} \mathrm{M}$ and $5 \cdot 10^{-3} \mathrm{M}($ the highest and lowest doses inducing a significant effect on cell growth). Flow microfluorometry was carried out $12,24,48$, and 72 hours after D-penicillamine treatment. Each value is the mean of 3 separate cytokinetic experiments (except at 72 hours $n=2$ ) \pm SD. 


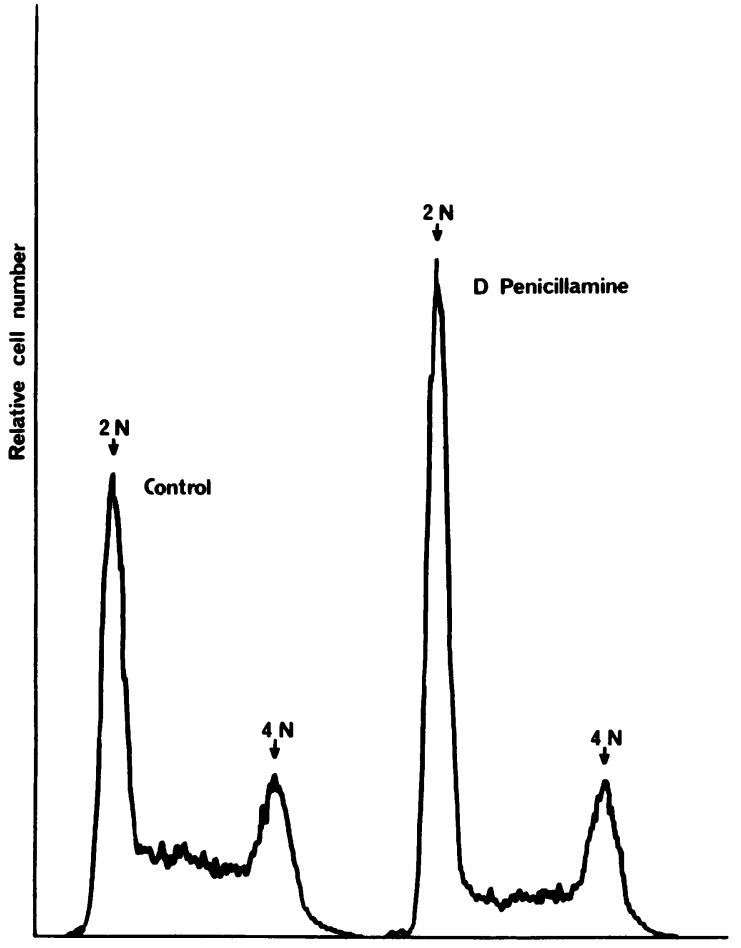

Red DNA fluorescence

Fig. 2 Typical DNA distribution histograms of asynchronous cultures of articular chondrocytes exposed to D-penicillamine. Growing cells of chondrocytes $\left(5 \times 10^{5}\right.$ cells per flask) were plated after 24-hour cultures with $5 \times 10^{-3} \mathrm{M}$ of D-penicillamine. Flow microfluorometry was carried out 24 hours after D-penicillamine treatment. Red fluorescence indicates the increasing concentration of DNA per cell. The arrows indicate DNA content corresponding to $2 \mathrm{~N}$ and $4 \mathrm{~N}$. A DNA content of $2 N$ corresponds to cells in $G_{1}$ and $4 N$ corresponds to $G_{2}$. Cells with DNA content intermediate between the $2 \mathrm{~N}$ and $4 \mathrm{~N}$ peaks are in $S$ phase. Total number of cells counted were 50000 for control and $5 \times 10^{-3} \mathrm{M}$. Note $G_{1}$ arrest and $S$ decrease of treated cells compare to control.

$M$ concentration with this prolonged incubation time. Moreover $12+12 \mathrm{~h}$ incubations did not amplify these phenomena (data not shown).

A 48-hour treatment with $10^{-3} \mathrm{M}$ was characterised by a slight significant increase in the relative number of cells in $\mathrm{G}_{0} \mathrm{G}_{1}$, whereas $5 \times 10^{-3} \mathrm{M}$ always led to a low percentage of cells in $S$, a high percentage of cells in $G_{0} G_{1}$, and a relatively high percentage of cells in $\mathrm{G}_{2} \mathrm{M}$ phase. However, at this time the control cells were no longer in the exponential growth phase (see Fig. 1) and density inhibited; comparing treated with control cells is therefore difficult.
At the 72nd hour (Table 3(d)) the percentage of cells in $\mathrm{S}$ phase of both control and $5 \times 10^{-3} \mathrm{M}$ treated cells was very low $(2 \%)$. However, the relative number of cells in $\mathrm{G}_{2} \mathrm{M}$ phase was higher in the treated cells $(19 \%)$ than the control $(9 \%)$.

In addition recovery experiments showed that no reversible effect was observed in cell phase distributions following incubation in a drug-free medium for 12 hours, but an increase of the number of cells in S phase appeared 24 hours after exposing the treated cultures to a drug-free medium (data not shown).

\section{Discussion}

The effects of D-penicillamine on articular chondrocyte cell proliferation were estimated by 3 independent assays - growth curve, clonability studies, and flow cytometry. The results show that concentrations of D-penicillamine in the range of $5 \times 10^{-3} \mathrm{M}$ and $5 \times 10^{-4} \mathrm{M}$ inhibit cell growth in a dose and time dependent manner. The recovery experiment showed that the concentrations employed produced transitory and reversible effects. A similar inhibition was observed on L 929 mouse fibroblasts by Langness and Decius ${ }^{15}$ and on fibroblasts from normal and scleroderma skin or synovial cells by Priestley. ${ }^{11}$ In addition D-penicillamine has been shown to inhibit mitogen-induced lymphocyte transformation. ${ }^{16}{ }^{17}$ All these authors found a concentration-dependent effect with doses similar to ours. This work indicates that another type of cell originating from the mesoderm is also sensitive to the action of D-penicillamine and confirms that the chondrocyte is a target cell for this drug. These results, coupled with earlier findings on the action of D-penicillamine on lymphocytes, macrophages, and synovial cells, suggest that the beneficial effects of D-penicillamine observed in the rheumatoid inflammatory process may be due partly to its action on the immunological cells, but also to the sum of its effects on the different types of cells affected by the inflammatory process.

However, the mechanism by which D-penicillamine acts on the cell proliferative capacity remains unknown. This study, using DNA flow cytometric analysis, showed that the reduction in growth rate observed was due to a marked decrease in the number of cells in $S$ resulting, especially from an accumulation of cells in $G_{0} G_{1}$ and also from a slowdown or a delay of cells in traversing $\mathrm{G}_{2} \mathrm{M}$. These phenomena appeared early; they were observed about 12 hours after the initiation of the treatment with the highest dose of $5 \times 10^{-3} \mathrm{M}$, and explain the slight growth inhibition effect observed after 24 hours with $5 \times 10^{-3} \mathrm{M}$. This decrease in the number of cells in the $S$ phase persists after 24- and 48-hour incubation with $5 \times 10^{-3} \mathrm{M}$ and is always accom- 
panied by an increase in the number of cells in $G_{0} G_{1}$ phase and the presence of an important number of cells in $\mathrm{G}_{2} \mathrm{M}$. For $10^{-3} \mathrm{M}$ these phenomena were delayed and of lower magnitude, since only an increase in the number of cells in $\mathrm{G}_{0} \mathrm{G}_{1}$ was noticed at the 48th hour. By the 48th hour, however, the cell distribution of control and treated cells was similar. The explanation for this finding is that control cells begin to reach their plateau phase (see Fig. 1) at this time and that the chondrocytes, like many other cells, remain in $G_{0} G_{1}$ during the plateau phase. Counts of the control and treated cells in a typical experiment gave, for example, at this time $1.1 \times 10^{6}$ cells in control culture dishes compared with about $0.3 \times 10^{6}$ and $0.8 \times 10^{6}$ cells for $5 \times 10^{-3} \mathrm{M}$ and $10^{-3} \mathrm{M}$ respectively. The decrease in $\mathrm{S}$ and the increase in the $G_{0} G_{1}$ phase of treated cells is therefore due to D-penicillamine and not to a densityinhibition phenomenon. After 72 hours of treatment the density-inhibited control cells showed only few cells in $\mathrm{S}$ and $\mathrm{G}_{2} \mathrm{M}$ phases. However, the $5 \times 10^{-3} \mathrm{M}$ treated cells still further showed an important percentage of cells in $\mathrm{G}_{2} \mathrm{M}$, confirming a slowdown in traverse $G_{2} M$ phase. This fact explains the high percentages noticed at the 24th and 48th hour for the $\mathrm{G}_{2} \mathrm{M}$ phase in the treated cells.

However, it would seem that a small percentage of cells remain in $\mathrm{S}$ phase even after 48 hours treatment $\left(9 \%\right.$ of cells in $S$ phase for $\left.5 \times 10^{-3} \mathrm{M}\right)$-i.e., the block of cells in $G_{0} G_{1}$ is incomplete. But it is possible that this phenomenon arises from the use of an asynchronous culture and that the cells observed in $S$ phase were previously in a part of $G_{1}$ in which D-penicillamine is ineffective, since at the 72 nd hour only $2 \%$ of treated cells are in $\mathrm{S}$ phase. This situation has been demonstrated for dexamethasone on NHIK 3025 cells. $^{18}$ Dexamethasone inhibited the cell growth only if the drug was added during the first half of $G_{1}$. On the other hand, the nonreversible $G_{0} G_{1}$ arrest following a 12-hour incubation in drug-free medium, which became reversible after a 24 -hour incubation, could be partly explained by the fact that the estimated duration of the $\mathrm{G}_{1}$ phase in chondrocytes was about 9-10 hours ${ }^{19}$ (and personal data). Indeed the time of 12 hours is very close to the length of $G_{1}$ phase and is lower than that of the cell cycle (18 hours), suggesting that transit of cells through the cell cycle is only partial and cannot be measured.

In addition, the slowdown in $\mathrm{G}_{0} \mathrm{G}_{1}$ could be compared to the block in $G_{1}$ observed with antiinflammatory steroidal and nonsteroidal drugs. The number of cells in the $G_{1}$ phase is increased by glucocorticoid anti-inflammatory drug treatment of HeLa cells, ${ }^{20}{ }^{21}$ lymphoblasts, ${ }^{22}$ and mouse lymphoma cells. ${ }^{23}$ A similar phenomenon was observed with a nonsteroidal anti-inflammatory drug, indomethacin, on HeLa cells ${ }^{24}$ and hepatoma cells. ${ }^{26}$ The mechanism by which the antiinflammatory drugs block cell growth in $G_{1}$ is not yet explained. Several reports ascribe the growth inhibition effect of glucocorticoids to the presence of specific intracellular receptors. ${ }^{27} 28$ So far as the uptake of D-penicillamine is concerned, the sparse conflicting data available at the moment ${ }^{29}{ }^{30}$ do not enable us to attribute the results described in this paper to an effect on intracellular or membrane binding.

It is important to clarify the mechanism of action whereby D-penicillamine and other antirheumatoid drugs can inhibit the cell growth. Our experiment suggested that D-penicillamine acted on cell proliferation through a biochemical process or a restriction point of the $G_{0} G_{1}$ phase and to a less extent through a biochemical process of the $G_{2} M$ phase. It could be due to single mechanism located in 2 parts of the cell cycle. Clarifying this mechanism would increase our understanding of its beneficial or nonbeneficial effect during treatment.

This work was supported in part by CNRS. LA no. 206 and INSERM PRC No. 131001.

We are indebted to Mrs C Hecquet for help with the manuscript.

\section{References}

1 Walshe J M. Copper chelation in patients with Wilson's disease. $Q J$ Med 1972; 62: 441-52.

2 Mac Gregor J T, Clarkson T W. In: Friedman $M$, ed Protein-metal interactions. New York: Plenum, 1974: 463-503.

3 Halperin E C, Thier S O, Rosenberg L E. The use of D-penicillamine in cystinuria: efficacy and untoward reactions. Yale J Biol Med 1981; 54: 439-46.

4 Rothermich N O, Thomas M H, Phillips V K, Bergen W. Clinical trial of penicillamine in rheumatoid arthritis. Arthritis Rheum 1981; 24: 1973-8.

5 Friedman M. Chemical basis for pharmacological and therapeutic action of penicillamine. Proc R Soc Med 1977; 70: $50-60$.

6 Zuckner J, Ramsey R H, Dorner R W, Gantner G E. D-penicillamine in rheumatoid arthritis. Arthritis Rheum 1970; 13: 131-8

7 Jaffe J A. Penicillamine treatment of rheumatoid arthritis: effect on immune complexes. Ann NY Acad Sci 1975; 255: 330-7.

8 Mohamed I, Barraclough D, Holborow E J, Ansell B M. Effect of penicillamine therapy on circulating immune complexes in rheumatoid arthritis. Ann Rheum Dis 1976; 35: 458-62.

9 Arrigoni-Martelli E, Binderup L. Enhancement of macrophage phagocytic activity induced by D-penicillamine in vitro and in vivo. In: Maini R N, Berry H, eds. Modulation of autoimmunity and disease. New York: Praeger, 1981: 104-10.

10 Lipsky P E, Ziff M. The mechanisms of action of gold and D-penicillamine in rheumatoid arthritis. In: Ziff $M$, Velo $G$, Gorini S. Advances in inflammation research. New York: Raven Press, 1982; 3: 219-35.

11 Priestley G C. Changes in the growth and metabolism of cells 
cultured from normal, sclerotic and rheumatoid connective tissue brought by D-penicillamine and by sodium salicylate. $J$ Invest Dermatol 1980; 74: 413-7.

12 Green W T. Behavior of articular chondrocytes in cell-culture. Clin Orhop 1971; 75: 248-60.

13 Crissman M A, Steinkamp J A. Rapid, simultaneous measurement of DNA, protein and cell volume in single cells from large mammalian cell populations. J Cell Biol 1973; 59: 766-71.

14 Fried J, Mandel M. Multi-user system for analysis of data from flow cytometry computer programs. Biomedicine 1979; 10: 218-30.

15 Langness U, Decius W. Die wirkung von D-penicillamine, azathioprin, aurothiopolypeptid, oxyphenbutazon und prednisolon auf die proliferation von L 929 Maüsefibroblasten und ihre glykosaminoglykansyntheseleistung in der monolayer kultur. Arzneim Forsch 1978; 28: 2202-7.

16 Lipsky P E, Ziff $M$. The effect of D-penicillamine on mitogen-induced human lymphocyte proliferation: synergistic inhibition by D-penicillamine and copper salts. J Immunol 1978; 120: 1006-13.

17 Room G, Roffe L, Maini R N. The inhibitory effect of D-penicillamine of human lymphocyte cultures stimulated by PHA; the antagonistic action of L-cysteine and synergistic inhibition by copper sulphate. Scand. J Rheumatol 1979; 28 (suppl): 47-57.

18 Bakke O, Eiknes K B. Cell cycle-specific glucocorticoid growth regulation of a human cell line (NHIK 3025). J Cell Physiol 1981; 109: 489-96.

19 Murison G L. Cell cycle of chondrocytes in vitro. Exp Cell Res 1972; 72: 595-600.

20 Kollmorgen G M, Griffin $\mathrm{H}$ J. The effect of hydrocortisone on HeLa cell growth. Cell Tissue Kinet 1969; 2: 111-22.
21 Adolphe $M$, Lechat $P$. Action of a steroid anti-inflammatory agent (methylprednisolone) on the cell cycle: study on synchronized cells. Biomedicine 1974; 20: 46-53.

22 Ernst P, Killmann S A. Perturbation of generation cycle of human leukemic blast cells by cytostatic therapy in vivo: effect of corticosteroids. Blood 1970; 36: 689-96.

23 Russell D H, Haddox M K, Gehring U. Effects of dexamethasone and dibutyryl cyclic AMP on polyamine synthesizing enzymes in mouse lymphoma cells. J Cell Physiol 1981; 106: $375-84$.

24 Adolphe M, Deysson G, Lechat P. Action of some steroid and non-steroid anti-inflammatory agents on the cell cycle: cytophotometric study of the DNA content. Rev Eur Etud Clin Biol 1972; 17: 320-3.

25 Bayer B M, Beaven M A. Evidence that indomethacin reversibly inhibits cell growth in the $G_{1}$ phase of the cell cycle Biochem Pharmacol 1978; 28: 441-3.

26 Hial V, de Mello M C F, Horakova Z, Beaven M A. Antiproliferative activity of anti-inflammatory drugs in two mammalian cell cutures lines. J Pharmacol Exp Ther 1977; 202: 446-50.

27 Gehring U. Specific receptors control steroid sensitivity in lymphoma cell hybrids. Mol Cell Endocrinol 1980; 20: 261-74.

28 Verbruggen L A, Salomon D S. Glucocorticoid receptors and inhibition of neonatal mouse dermal fibroblast growth in primary culture. Arch Dermatol Res 1980; 269: 111-26.

29 Binderup L, Arrigoni-Martelli E. $\left[{ }^{14} \mathrm{C}\right]-\mathrm{D}$-penicillamine: uptake and distribution in rat lymphocytes and macrophages. Biochem Pharmacol 1979; 28: 189-92.

30 Lodemann E. Transport of $\mathrm{D}$ and $\mathrm{L}$ penicillamine by mammalian cells. Biochem Biophys Res Commun 1981; 102: 775-83. 